UDC 101.9+17.021.2

DOI https://doi.org/10.24195/sk1561-1264/2019-2-5

Ilyina Anna

Master's Degree in Philosophy and Sociology Department of State Institution «South Ukrainian National Pedagogical University named after KD Ushinsky»

\title{
SELF-REALIZATION OF PERSONALITY IN THE CONDITIONS OF SOCIOCULTURAL TRANSFORMATION
}

\begin{abstract}
In our opinion, it is more expedient to analyze self-realization of the person in the conditions of sociocultural transformation proceeding from the sociocultural bases. With this approach, we will be able to give priority to the values of the individual, its system of value orientations, the structure of the value environment of Ukrainian society.

The influence of factors of socio-cultural development of society begins from birth and their very presence is directly dependent on the level of socialization, sociocultural personality types prevailing in this particular society. The most important factors we consider: the economic life of society; morality as a regulator of social behavior; sociocultural reality; cultural universals.

Under the self-realization of the personality we understand the process that provides the systemic essence of the personality, its Outlook, identification and development of personal abilities and based on the factors of sociocultural development of society.

For effective self-realization the person should designate the place in the world of sociocultural relations, being guided by needs of society, its cultural priorities and features.

The modern period of development of Ukrainian society has led to the problem of lack of demand for both the person and his professional qualities. As a result, the high development of social fluctuations, this caused the progression of mass anomie.

In this situation, the best option seems to be the formation of a system of value orientations based on the ideals of individual freedom, on mutual respect, interaction and exchange of values that are positive for society, and are the Foundation for the highest value-the meaning of life.

The success of self-realization depends on the humanistic orientation of society. After all, the progressive movement of world structures into postmodern society with the formation of a new system of values is generally recognized on the scale of humanity.

Modern society, choosing humanization as the Foundation of its existence, seeks to compromise with the opposite side on the basis of mutual respect, recognition of the value of another opinion, another sociocultural system. Therefore, the humanistic attitude of the individual to his own interests, to the interests and motivations of others is conditioned by concern for today and tomorrow. And the practical nature of the humanistic attitude to reality is not tomorrow, but today, during the life of this generation, to create for him, and therefore for himself, human conditions of life and opportunities for self-realization.

Key words: personality, self-realization, personal fulfillment, sociocultural, transformation, sociocultural transformation, sociocultural reality, morality.
\end{abstract}

Modern Ukrainian society is undergoing a period of radical transformation when changes are subject not only to some of the social structures and institutions, but also the values, values, moral and legal norms and priorities. Therefore, today one of the most pressing issues is the self-realization of the individual in transforming society.

It should be noted that the problem of self-realization in its philosophical and ethical aspects of the phenomenon in the XX century scientists such as John Mackenzie, E.Mune, Benedetto Croce, to explore the meaning of life, human guidance. Enough is developed and various aspects of the structure of personality, its socialization and orientation. Thus, the development of personality, the essence of its value studied I. Cohn [1] M. Kagan [2], S. Rubinshteyn [3]. They noted the importance of the activity approach to the study of personality, the relationship of social, biological and psychological behavior and motivation, allocate the value of the value in the structure of activity and culture. In recent years, scientists have been paying attention to the basic analysis of the transformation processes in the society. T. Zaslavsky analyzes the historical and cultural features of Russia in the context of social transformation [4] AT. 
Modern Ukrainian researchers prefer to consider the effect of the value of value orientations on the transformation processes. Among the rather large amount of work stand monograph A. A. Kavalerova which revealed different approaches to the classification of values and value orientations [6]. Note also A.Reznika research, focusing on the political identity of the person [7]. Golovakha E., A.Handle, S. Kataev interested features category «sociocultural», its effect on the individual, is not without reason, assuming that in the present conditions, this concept is one of key $[8,9,10]$.

However, the problem of self-identity in a transformed society analyze extremely inadequate, preferring it only designate or explore in a different context. So, V. Mulyar focuses on philosophical and cultural analysis of personal fulfillment [11] and I. Chheaylo focuses on the social and philosophical aspect of this subject [12]. However, they stop at common points, without going into the specifics of our stated problems. At the same time, Mr. Nesterenko, exploring the self-realization of the person «in terms of spontaneity of social transformations», found it necessary to focus on the social context of synergy [13].

In our view, self-realization of the individual in a social and cultural transformation should be analyzed on the basis of socio-cultural grounds. With this approach, we will be able to give priority to the values of the person, its system of value orientations, structure of values among Ukrainian society.

Based on the above, the purpose of the work is to study the factors of personality self-realization in the conditions of social and cultural transformation.

Goal match the following tasks:

- study the nature and characteristics of the process of self-realization of the person in the conditions of social and cultural transformation;

- the study of social and cultural development of the individual factors;

- analysis of the specifics of self-identity in the modern Ukrainian society, the relationship of the individual self with the values of the Ukrainian society.

The object of the research is self-realization.

The subject of the study are the features of self-realization in the conditions of social and cultural transformation.

In the ordinary sense for self-realization is usually meant the realization of their own potential. In science, the term «self-realization» (self-actualization) became popular due to the hierarchy of needs theory proposed by Abraham Maslow in 1954 [14] and further developed [15, 16]. According to his theory of self-realization can be achieved only subject to the satisfaction of all other biosocial needs.

However, in the sociological analysis of the term, it seems necessary disclosure of the broader values of self-realization, considering the identification and development of the individual's personal abilities in all fields of activity. Note that the self-study of the problem of personality is impossible without understanding the essence of the person, its orientation, values system, a clear distinction of categories: «person», «individual», «personality», «personality».

Man is regarded as biosocial being, where there is unity of biological and social. Defined here will be to assess the ability to give preference to the most important, significant. The concept of «person» is better to use when it comes to generic properties, qualities, differences.

At the same time, if we are talking about a particular person, it is emphasizing its specifications, correct to use the term «individual», highlighting its integrity.

In individual displays a specific and unique incarnation of the general in person. «Identity» is used to denote the unique properties of the individual displays and [17, p. 12].

Personality is a social identity, stressing in man not only social skills, but also personal and social characteristics. The personality is formed and developed through their individuality.

Among individual personality indicators that allow for the predicted social engineering of society, the most important seems to us the system of value orientations, which allows to analyze the trend in the development of society.

value orientations of the individual system is based on values, acting as life goals and the main means of achieving these goals. Value orientation not only regulate individual behavior, but also to define it. In this connection, it is possible to consider the value orientation as the highest level dispositional personality structure. 
Deeply aware of the value orientation have a regulating, motivating impact on individuals, even if for some reason it did not reach life goals. Then the value orientations encourage the person to look for opportunities and ways to achieve these goals, ways to overcome the existing obstacles. Defining its system of value orientations, personality reveals the degree of awareness of cultural values of the society, at the same time showing the level of their culture, their views, outlook, understanding of the purpose and meaning of life.

Particular significance in the system of value orientations is the integration of socially important values of life as a result of past and present generations, as well as the design of the individual the ability to live for the future. This process can be successful only if a positive solution to the problem of self-realization of the individual in terms of social and cultural transformation.

The effectiveness of self-realization, in our opinion, depends on the interdependent and interrelated factors of socio-cultural development of society. These factors indicate the external framework of self-realization and influence on individual behavior, it adopted the most important decision-making process, changing the system of value orientations.

The influence of socio-cultural factors of social development begins at birth and their very presence is in direct proportion to the level of socialization, socio-cultural personality types, prevailing in a particular society. The most important factors we consider: the economic life of society; morality as a regulator of social behavior; social and cultural reality; cultural universals.

The economic life of society acts as a complex interaction of objective and subjective aspects of social life. The objective interests of the people expressed that they objectively useful and beneficial. We are talking about the best ways and means to meet the needs. Each new generation finds the already existing economic structure, which directly and indirectly affect the consciousness of the people, their needs, interests, values, social dispositions. At the same time there is a subjective aspect of economic life, which is expressed in the manifestations of the inner world of the individual, his psychological make-up and intelligence. This includes any subjective perception of various economic phenomena and subjective perceptions of them. Such representations may be directed to the usefulness of the goods, the role of money, the specificity of the contributions and earnings, promotion of the social ladder through a variety of economic levers, etc. In this understanding of the economic life of the features will certainly affect the self-identity, especially if the said process will take place under conditions of social change. It should be added that in Ukrainian society, a radical breakdown of the old (communist-socialist) economic model and replacing it with a model of «wild capitalism» has led to a huge socio-cultural gap between the generations, literally «break» the country into different camps in terms of various socio-cultural understanding of the possible ways of achieving economic prosperity. If these processes will occur in the conditions of social changes. It should be added that in Ukrainian society, a radical breakdown of the old (communist-socialist) economic model and replacing it with a model of «wild capitalism» has led to a huge socio-cultural gap between the generations, literally «break» the country into different camps in terms of various socio-cultural understanding of the possible ways of achieving economic prosperity. If these processes will occur in the conditions of social changes. It should be added that in Ukrainian society, a radical breakdown of the old (communist-socialist) economic model and replacing it with a model of «wild capitalism» has led to a huge socio-cultural gap between the generations, literally «break» the country into different camps in terms of various socio-cultural understanding of the possible ways of achieving economic prosperity.

Morality regulator social behavior can reduce the difference between different socioeconomic and socio-cultural groups provided a fine pattern on humanization relationship. In the field of social and personal morality is inclusive. In all of this, morality allows for permanent rulemaking people, in which the main figure is an individual, speaking at the same time, and as the creator of his own life. Then claims will be, first of all, to himself. What is particularly important for social and cultural transformation of society, when the regulatory, value-oriented and socializing side of morality manifested primarily.

In this case, the socio-cultural reality will be the most complete expression of the results of social and cultural transformation, as a process of culture functioning in the system of social relations. The 
socio-cultural reality- it is fixed in the performance and characteristics of the culture's ability to influence social development [18]. Being on the edge of social and cultural, socio-cultural reality is a kind of border zone of their interaction, ground testing possibilities of cooperation and understanding for individuals, social groups and society. The new social and cultural reality of Ukraine has the opportunity to capture the modern social and cultural problems of the state, to synthesize the development priorities, to offer a way out of the situation of social chaos on the basis of socio-cultural worldview, humanistic attitude to reality.

A special role in the socio-cultural development of cultural universals play society. With its bio-psycho-social conditions, they are fundamentally transformed the culture and have a sense of self-valuable for people [19, p. 74]. Cultural universals represent valuable relationships between people, providing the ability to build a hierarchy of this particular society of values in a particular historical period.

These factors socio-cultural development provide the basis for self-realization in the conditions of transformation of society. And the person, taking into account their behavior when these factors, it is better to acquire new social norms, values, and other elements of culture, it (the person- EB) positively manifest social activity and, as a consequence, a high level of the interaction of various subcultures.

Thus, under the self-realization, we understand the process of ensuring the system the essence of personality, its outlook, the identification and development of personal skills and is based on factors of social and cultural development of society.

Self-realization process affects the changing needs of the individual. First, it is a meta-needs (need for justice, prosperity, freedom, etc.), as they are called Maslow. These needs can reasonably be attributed need for fulfillment. For effective self-person must indicate their place in the world of social and cultural relations, focusing on the needs of society and its cultural priorities and characteristics.

The modern period of development of the Ukrainian society has led to the problem of lack of demand as the man himself, and his professional qualities. As a result of the high development of social fluctuations, which caused a massive progression of anomie. So, stevedores began to earn more than university professors. Physical work mostly paid and therefore is valued more intelligent. Naturally, the self-realization of the individual in such circumstances is hardly possible. A person can not reach the desired, if no demand or profession, or paid below subsistence. But we are talking about professions, belonging to the middle class (school teacher, psychologist, doctor, engineer, etc.). Dissatisfaction with personality, her sense of uselessness lead to very negative consequences for society.

In this situation, the best option is to create a system of value orientations based on the ideals of freedom of the individual, on mutual respect, cooperation and mutual exchange of values, wearing positive for society, and is the foundation for the highest value- the meaning of life.

Unfortunately, this path is thorny enough for several reasons.

First, the meaning of life is such a content, which a man gives his own existence and, consequently, is understood as primarily a unique and individual phenomenon [22, p. 74]. It turns out that the meaning of life is present in every act of the individual, but, strictly speaking, is not a clearly defined social message, because it has a purely individual coloring. Man is based primarily on their needs, and the meaning of his life is manifested in self-level. Incidentally, the «Philosophical Dictionary,» edited V.Shinkaruka explains the meaning of life as a self-realization of the individual [23, p. 634].

Secondly, setting benchmarks for themselves the meaning of life, a person can raise or lower the level of their freedom, adapting to the existing norms and values, taking into account the political structure of society and the personal economic dependence on the adopted position. This means that the limited and self-realization.

Thirdly, it is necessary to take into account the original strips, put in front of the individual. They may be conventional, normal, and may- too high or too low. In this situation the fulfillment process can easily pass during the fluctuation step and then predict the end result is not possible.

Therefore, we are talking about the particular features of the interdependence of social phenomena values of society. 
In the modern Ukrainian society has developed a versatile social and cultural situation, characterized by a sharp conflict between the old and the new. The conflict is complicated by the state of anomie, when the old norms and values do not work, and the new ones have not had time to emerge. In addition, the system of social sanctions, or inactive, or refers to people, social groups very selectively. After all, one and the same act different individuals, even representatives of different subcultures, may be punished or encouraged absolutely incomparable. So, if an ordinary man driving a car is to blame for the death of a pedestrian, he would be punished. But the son of «dignitaries» and certainly cost a scolding parent. Inequality before the law creates inequality in self-realization, the realization of life dissatisfaction, lack of willingness to adapt to changes in society. Of course, in any case, anomie characteristic of the period of social transformation. However, the level of anomie is a significant indicator of the possibility of overcoming the destructive state of any sociocultural system. Ukraine's transition from a totalitarian social system towards democratization, the desire of the Ukrainian people to build a democratic state (as evidenced by the results of the elections) provide hope for successful overcoming of anomie.

The desire for social freedom of the Ukrainian people has led to a significant increase in social activity. People were included in the process of interaction, mutual exchange of opinions, sparking an exchange ideals, needs, interests, and can lead to what is desirable, and mutual socio-cultural, linguistic, ethnic values, as self-identity problem will be solved by mutual social adaptation.

The success of self-realization depends on a humanistic orientation of the society. After all, in the scale of humanity universally recognized world progressive movement structures in the postmodern society with the formation of a new system of values. The population of the first countries to industrialize (and now in the economically leading countries in full swing post-industrialization), puts emphasis on postmaterial values, giving priority to the quality of life. The value system of the postmodern high priority is personal self-realization, the humanization of society as a fundamental value, which is based on a sense of existential security. This point of view is based on the humane treatment of the person to: 1) itself; 2) another person; 3) the community; 4) the future; 5) The most vulnerable members of society (children and elderly).

Attitudes toward people, other social, cultural, ethnic, linguistic groups should be based on the values of humanization, which are based on morality, tolerance and compassion. When tolerance is taken into account the value and the intrinsic value of other, often opposing views. Tolerance of an individual is based on an understanding of inferiority discriminatory point of view, the most significant recognition of human value. Tolerance for different lifestyles necessarily built on sympathy. Empathy provides opportunities to impose their views, and is based only on the basis of objective evidence. Only in this case, the maximum possible self-realization, not limiting the possibility of self-realization of others. Empathy allows us to estimate the diversity of human interests,

Modern society, choosing the foundation of its existence, humanization, tends to compromise with the other party on the basis of mutual respect, recognizing the value of a different opinion, a different socio-cultural system. Therefore, humanistic attitude to the person's own interests, to the interests and motivations of other due to concern for the present and the future. A practical humanistic attitude to reality is to not tomorrow, but today, when the life of the generation to create it, and thus itself, human living conditions and opportunities for self-realization.

Thus, the humanistic orientation of the person in the process of self-transforming Ukrainian society is indicated in the relation of man to himself, to others, to society. This ratio is based on adherence to the principles of tolerance and compassion, promote the harmonious development of personality.

Findings:

1. Self-realization- a process that provides a systematic nature of the individual, his worldview, identification and development of personal skills and is based on factors of social and cultural development of society. The most important factors are: the economic life of society, morals as the regulator of social behavior, social and cultural reality, cultural universals.

2. Self-realization will be effective, if the formation of the value orientations of the system took place on the foundation ideals of individual freedom, the sense-life orientations, mutual respect and cooperation. 
3. In transforming Ukrainian society, personal fulfillment is complicated by the conflict of generations, anomie, life dissatisfaction sufficiently large number of people, social groups, the problem of transition from a totalitarian political system to democratic norms and values.

The success of self-identity in the modern Ukrainian society depends on a humanistic orientation of the society, based on morality, tolerance and compassion.

\section{References}

1. Кон И. С. Социология личности. Москва, 1967. 383 с.

2. Каган М. С. Философская теория ценности. Санкт-Петербург, 1997. 205 с.

3. Рубинштейн С. Л. Принципы творческой самодеятельности Вопросы философии.1989. № 4. С. 89 - 95 .

4. Заславская Т. И. Современное российское общество: Социальный механизм трансформации: Учеб. пособие. Москва, 2004. 400 с.

5. Ядов В. А. Некоторые социологические основания для предвидения будущего российского общества / Россия реформирующаяся; под ред. Л. М. Дробижевой. Москва, 2002. C. $349-363$.

6. Кавалеров А. А. Цінність у соціокультурній трансформації: Монографії. Одеса, 2001. $224 \mathrm{c}$.

7. Резнік О. Політична само ідентифікація особистості за умов становлення громадянського суспільства. Київ, 2003. 184 с.

8. Головаха Є. Суспільство, що трансформується. Досвід соціологічного моніторингу в Україні. Київ, 1997. 155 с.

9. Ручка А. А. Особенности системной трансформации современного украинского общества . Современное общество. 1994. №4. С. 6 - 15.

10. Катаев С. Л. Модернизация общества и социокультурные процессы. Запорожье, 1994. 204 c.

11. Муляр В. І. Самореалізація особистості як соціальна проблема (філософсько-культурологічний аналіз). Житомир. 1997.214 с.

12. Чхеайло I.I. Самореалізація особи (соціально-філософський аналіз): дис...канд. філос. наук: 09.00.03. - Харків, 2000. 181 с.

13. Несторенко Г. Особистість у нелінійному суспільстві: Монографія. Запоріжжя. 2004.140 c.

14. Maslow A. Motiwation and Personaliti. New York, 1954. 411 p.

15. Маслоу А. Новые рубежи человеческой природы. - Москва. 1999. 425 с.

16. Маслоу А. Психология бытия. Киев, 1997. - 300 с.

17. Боринштейн Е. Р., Кавалеров А. А. Личность: ее языковые ценностные ориентации. Одесса, 2001. - 168 с.

18. Борінштейн С. Р. Нова соціокультурна реальність в Україні та їі характеристики. Перспективи. № 4 (24). Одеса, 2005. С. 18 - 24.

19. Левяш И. Я. Культурология: Курс лекций. Минск, 1998. 544 с.

20. Головаха Е. И., Панина Н. В. Социальное безумие: история, теория и современная практика. Киев, 1994. - 168 с.

21. Паніна Н. Молодь України: структура цінностей, соціальне самопочуття і морально-психологічний стан в умовах тотальної аномії. Соціологія: теорія, методи, маркетинг. 2001. № 1. С. 5 - 26.

22. Маркин Ю. Предназначение человека. Диалог. 1996. № 9. С. 73 - 75.

23. Філософський словник. / за ред. В.І. Шинкарука. - 2-ге вид., перероб. і доп. - Київ, 1986. $-800 \mathrm{c}$. 


\begin{abstract}
Ильина Анна Сергеевна
магистрант кафедры философии и социологии

Государственного учреждения «Южноукраинский национальный педагогический университет имени К.Д. Ушинского»
\end{abstract}

\title{
САМОРЕАЛІЗАЦІЯ ОСОБИСТОСТІ В УМОВАХ СОЦІОКУЛЬТУРНОЇ ТРАНСФОРМАЦЇ̈
}

На наш погляд, самореалізацію особистості в умовах соиіокультурної трансформації доцільніше аналізувати виходячи з соиіокультурних підстав. При такому підході ми отримаємо можливість приділити першочергову увагу цінностям особистості, ї̈ системі иіннісних орієнтацій, структурі иіннісного середовища украӥнського суспільства.

Вплив чинників соціокультурного розвитку суспільства починається з народження $i$ сама їх присутність знаходиться в прямій залежності від рівня сочіалізації, типів особистості, щзо переважають у даному конкретному суспільстві. Найбільш важсливими факторами ми вважаємо: економічне життя суспільства; мораль як регулятор сочіальної поведінки; соиіокультурну реальність; культурні універсалії.

Під самореалізацією особистості ми розуміємо процес, щзо забезпечує системну сутність особистості, ї̈ світогляд, виявлення і розвиток особистісних здібностей $і$ базується на факторах сочіокультурного розвитку суспільства.

Для ефективної самореалізаціїлюдина повинен визначити своє місие в світі соиіокультурних відносин, орієнтуючись на потреби суспільства, його культурні пріоритети і особливості.

Сучасний період розвитку українського сочіуму призвів до проблеми незатребуваності як самої людини, так $і$ ї̈ професійних якостей. В результаті високий розвиток сочіальних флуктуацій, щзо викликало прогресування масової аномії.

В иіий ситуації найкращчи варіантом представляється формування системи ціннісних орієнтацій, заснованих на ідеалах свободи особистості, на взаємоповазі, взаємодію та взаємообмін цінностями, які носять позитивний характер для суспільства, i є фундаментом для вищої цінності - сенсу життя.

Успішність самореалізаиії особистості залежить від гуманістичної спрямованості соиіуму. Адже у масштабі людства загальновизнано поступальний рух світових структур в суспільство постмодерну з формуванням нової системи цінностей.

Сучасне суспільство, вибираючи фундаментом свого існування гуманізацію, прагне до компромісу з протилежною стороною на основі взаємоповаги, визнання цінності іншої думки, іншої соиіокультурної системи. Тому гуманістичне ставлення особистості до власних інтересів, інтересів і спонукальних мотивів інших обумовлено турботою про сьогоднішній $i$ завтрашній день. А практичний характер гуманістичного відношення до дійсності полягає в тому, щоб не завтра, а сьогодні, за життя иьього покоління створити йому, а значить $і$ собі, людські умови життя і можливості для самореалізаиії.

Ключові слова: особистість, самореалізачія, самореалізація особистості, соціокультурне, трансформація, соиіокультурна трансформація, суспільство, щчо трансформується, сочіокультурна реальність, мораль. 